\title{
The Research on Liquidity Risk Management of China's Commercial Banks
}

\author{
Yayi Xiao \\ School of Economics, Jinan University, Guangzhou, China \\ Email: anne_xiao_21@163.com \\ Received 27 February 2016; accepted 26 March 2016; published 29 March 2016 \\ Copyright (C) 2016 by author and Scientific Research Publishing Inc. \\ This work is licensed under the Creative Commons Attribution International License (CC BY). \\ http://creativecommons.org/licenses/by/4.0/ \\ (c) (i) Open Access
}

\begin{abstract}
Liquidity has long been known as the "lifeline" for commercial banks, it not only lays the foundation for all activities of commercial banks but also plays a decisive role in maintaining the economic stability of the whole country and even the world. Since the 1990s, commercial banks of our country have been exposed to problems such as liquidity inadequacy and liquidity risk due to institutional and structural reasons. This paper establishes the ARMA model for empirical analysis and brings up corresponding suggestions for the liquidity risk management for China's commercial banks.
\end{abstract}

Keywords

Liquidity Risk, Risk Management, Commercial Banks, Liquidity Gap, ARMA Model

\section{Introduction}

In recent years, the global financial crisis triggered by the sub-prime mortgage crisis in the United States continues to intensify and greatly influences the global economy. In the wake of the take-over of Fannie Mae and Freddie Mac by the U.S. government, Lehman Brothers Holdings' filing for bankruptcy protection and the century-old Merrill Lynch being beset with bankruptcy, the global financial system faces the greatest ever crisis since 1929. Little though the influence of previous financial crises is over commercial banks of our country, China's banking industry is bound to be more closely connected with the international financial market. As promised when entering the WTO, China's banking industry has fully opened. Chinese banks have to face the overall challenge brought by foreign banks with advanced management technique. In pursuit of high profits as well as strong competitiveness, commercial banks of our country strengthen the bond with international financial market, which makes the domestic financial system more susceptible to international events imperceptibly.

There are several long-standing issues concerning China's commercial banks, such as low profitability, high rate of non-performing assets, low capital adequacy ratio, maturity mismatching of assets and liabilities, low degree 
of marketization and backward risk management techniques. With poor capability of dealing with and resisting risks, commercial banks of our country are confronted with serious systematic risk under the market economy environment which is always filled with international financial crisis proneness. China's commercial banks are accordingly in urgent need of improving risk management technique so as to prepare themselves against all sorts of risks, especially liquidity risk. Risk Management plays a decisive role in the development of commercial banks, and is deemed the emphasis and difficulty of asset-liability management and financial risk management by commercial banks around the world [1]. Liquidity risk management of global banking industry has experienced a development process in which causes for risks tend to be much more complex and banks' management turns systematically and steadily with increasingly strict supervision. Early liquidity risk management largely focused on the liquidity management of assets. As the financial market moves forward, liquidity management gradually transfers into liquidity management of liabilities, balanced liquidity management and some other stages [2].

Liquidity risk management has been the focus of worldwide study for the past years. Kashyap, Rajan and Stein [3] built the liquidity decision model for commercial banks. It was found out that liquidity reserves had positive correlation with the amount of demand deposit and credit loan, and was negatively related to liquidity cost. Thomas and Wang [4] believed that when banks were in the face of a liquidity shock or credit shock, it was feasible to dissolve the risk through adding reserve and capital or by means of asset securitization. Elena Carletti [5] made an analytic research into the influence of bank amalgamation on loan race, reserve holdings and total liquidity, which pointed out that mergers of commercial banks could improve the accuracy of liquidity demand estimation and modify the impact of liquidity shock on banks.

The study of bank liquidity in China has a late start and still stays at the primary stage. With regard to the causes of liquidity, Changhui Yao (1997) investigated the fundamental causes of liquidity risk for banks in China and concluded four manifestations of liquidity risk. The research also put forward that the uncertainty of sources and applications of funds together with the contradiction between liquidity and profitability brought about banks' liquidity risk. Zhenghui Fu (2005) stated that the most critical part of commercial banks' liquidity risk management was that abundant capital should be ready for the financial risk hit which had the characteristics of ambiguity, hysteresis and long-range. Capital was regarded as the last barrier to risks for commercial banks. Yu Jin (2006) suggested that innovating the techniques and methods of liquidity management was able to effectively relieve liquidity risk. He also presented two aspects for formulating liquidity strategy: one is to take liquidity gap as the main management index, the other is to pay attention to the influence of external market volatility on capital flow as well as prices while compartmentalizing asset and liability maturity and measuring the supply and demand of funds. Liang Zhou (2009) studied the "Principles for Sound Liquidity Risk Management and Supervision" issued by Basel Committee on Banking Supervision, and mentioned that we had to take in and draw lessons from the advanced experience of liquidity risk supervision from international banks so that the liquidity risk supervision system of China could be refined. Minghua Dai and Zheng Yi (2010) put forward the effects of the financial crisis and the corresponding tactics for commercial banks against the predicament under the financial crisis with an eye to both the macroeconomic policy and banks themselves.

Although not a few articles related to bank's liquidity risk management have been written, most of them consider liquidity risk management from the view of banks themselves or only work over investigating the liquidity position of banks. Articles about bank's liquidity risk management from the standpoint of the open economy are limited in number and those below the setting of the global financial crisis are even rare. This paper seeks to start from the state of the world economy, analyze the liquidity risk management of commercial banks in China through a new way and figure out some applicable advises.

\section{Constraints on Liquidity Risk Management}

\subsection{Backward Management Concepts and Weak Risk Awareness}

International liquidity risk management of commercial banks had transited to substantive asset-liability management, but China's liquidity risk management started late and cannot be taken as liquidity risk management on real significance. The governance structure of modern commercial banks needs for further improvement, as is with the legal system and the risk control system of risk management [6]. Meanwhile, liquidity risk management of China's commercial banks mainly relies on the central bank forcing without self-consciousness. Over a long period of time, national credit support makes people think that government will bear all the risks that banks 
create and liquidity risk will not happen even if banks fail. Moreover, the steady stream of saving deposit from residents forms the second reason for commercial banks not having to worry about their liquidity. As a bank, the real commercial reform will arrive sooner or later and the national credit support will open gradually. In the long run, cultivating financial institutions that have real core competitiveness is the basic aim of the national reform of commercial banks. Therefore, commercial banks had better strengthen not only publicity and education but also the awareness and wise management of liquidity risk, making sure to have the sense of urgency and properly deal with the relationship between safety, liquidity and profitability.

\subsection{Unreasonable Asset-Liability Ratio Management}

The essence of asset-liability ratio management is a kind of restraint and regulatory mechanism from the central bank to commercial banks, and also a macro management method [7]. Not basing on themselves leads to the status quo where banks' liquidity risk management only lays emphasis on the good performance of liquidity, lacking attention to improving liquidity risk management capacity, which imposes restrictions to banks' flexibility and thus they cannot adjust to changes in the market. We consider the imperfection of the proportional index system from the following two aspects: One is the lacking of hierarchy for the proportional index. The assetliability ratio management is the comprehensive evaluation index carried out by the People's Bank of China, aiming at the head offices of the commercial banks. Although the asset-liability ratio management requires the assessment of the branches of commercial banks according to the decomposed index of the head office, there is no decomposed index in practice. The other is the inflexibility of the internal control index for commercial banks. The internal and external environment for each commercial bank differs, so Central bank's asset-liability ratio standard with the general representative is not always the best choice for any state of operation for every bank.

Then, we keep an eye on the constraints from external environment. Firstly, administrative intervention restricts banks smoothly carrying out of the asset-liability ratio management. Commercial banks are independent economic entities, but the arrangement to set up branches according to administrative regions has not changed yet, which makes administrative intervention unavoidable. Secondly, poor economic performance of the enterprises limits the process of banks' asset-liability ratio management. In recent years some of the state-owned enterprises have high debt-to-equity ratio and low debt-paying ability, making the recovery of loans and interests difficult for commercial banks and worsening the banks' credit assets. Firms with good performance have wide financial channel and sufficient funds so that they do not need plenty of loans. Thus, banks had to obtain high profits on the basis of guaranteeing the safety of credit funds and present the full implementation of asset-liability ratio management with difficulties. Thirdly, the financial market system is not yet perfect and the adjustment for structure of assets and liabilities is unattainable. Our financial market still stays in the stage of cultivation and perfection. The asset and liability management of commercial banks is deficient in due market mechanism, and the investment market is unable to be market-oriented in choosing investment direction and optimizing the asset structure.

\subsection{Imperfection of the Internal Control System}

Up to now, commercial banks of our country haven't established scientific liquidity risk management system. There is deficiency in the early-warning mechanism, medium-term prevention and transfer of the controlling mechanism and losing-risk reducing mechanism within the banks. The method we use for forecasting liquidity demand is limited to the amount of cash on hand and the amount paid; and the forecast of loan demand is relatively ignored. At the same time, commercial banks are absence of monitoring mechanism and the ability of identifying and eliminating risk using banks' resources efficiently under complex conditions. The ways that banks use are backward, mostly fastened to asset-liability ratio management framework without corresponding software and hardware to use foreign risk management experience and methods for reference. Moreover, there's no specialized liquidity risk management agency to help with the integrity of plans and the scientificity of strategic decision.

\subsection{Incomplete Development of Money Market and Limited Risk Management Tools}

Within the international financial market, on the one hand diversified financial derivatives are emerging in an endless stream and financial innovation services are occupying an increasingly large proportion, but on the other 
financial risks and market uncertainty continue to strengthen, therefore banks' risk management tends to be increasingly complex [8]. Nevertheless, commercial banks in China lag far behind western countries in the use of innovative financial products and financial instruments. The fact that our money market is not perfectly developed leads to the big gap between commercial banks' liquidity risk management tools and techniques of our country and that of developed countries. The small scale, little market transaction subject and vacancy secondary market all directly restricted commercial banks' ability of assets realization and getting active liabilities, thus affecting commercial banks' capability of liquidity risk management.

\section{The Model}

As noted in the previous chapters, the mismatching of liquidity demand and supply for capital is a main reason for the appearance of liquidity risk, which refers to the liquidity gap in terms of index. During a future period of time, the difference between the total amount of capital the bank can obtain and the total amount of debt the bank is due to repay directly reflect bank's liquidity capability, which is also defined as the liquidity gap. When the value of the liquidity gap is positive, bank's liquidity supply is not enough to cover its liquidity demand; the bank has to raise extra funds in order to maintain the stability of bank's liquidity and avoid liquidity risk. When the value of the liquidity gap is negative, it suggests that the commercial bank has liquidity surplus with sufficient liquidity but poor profitability; the manager had better invest the excess funds into projects with high rate of return and achieve a win-win situation. Therefore, this paper choose liquidity gap as the index to measure liquidity risk so as to better analysis the liquidity risk management of China's commercial banks under the financial crisis and establish a liquidity risk prediction model for banks on the basis of the liquidity gap.

The formula for the liquidity gap is as follows:

$$
L G=D-S
$$

where $L G$ : liquidity gap; $D$ : liquidity demand; $S$ : liquidity supply.

The estimate for liquidity gap concerns two variables, namely liquidity demand and liquidity supply. Zeng Lin (2012) stated the following definition in his research: for a commercial bank, the source of liquid funds are mainly customer deposits, non-deposit service income, loans due for repayment by the customers, assets sold by the bank and bank's borrowed funds from the money market; and the liquid funds are ready to be used to fulfill the demand for customer withdrawal, demand for bank loans, loan demand besides repayment of loans and demand for investment. Owing to the statistical account differences between China's commercial banks, it is difficult to unify the figures. We hence define liquidity demand as the sum of the loans, securities and investments, and liquidity supply as the sum of the deposits and financial bonds. For the purpose of deriving better analysis of the liquidity condition for China's commercial banks under the financial crisis, this paper employs the method of empirical analysis based on the ARMA model, taking liquidity gap as metrics and selecting the statistical data of the banking industry of China monthly from year 2004 to year 2015, which comes from the website of the People's Bank of China.. Taking the long time span and the fact that the liquidity demand and supply for banks are greatly influenced by economic cycle and the financial market condition into consideration, we take logarithm and difference of the liquidity gap, that is:

$$
R_{t}=\ln Y_{t}-\ln Y_{t-1}
$$

where $R_{t}$ : object of the study; $Y_{t}$ : liquidity gap of current month; $Y_{t-1}$ : liquidity gap of last month.

\section{Empirical Results}

\subsection{Tests of the ARMA Model}

We have defined liquidity demand as the sum of loans, securities and investments and liquidity supply as the sum of deposits and financial bonds at the beginning of this chapter. In order to carry out better empirical analysis, this paper obtains the monthly data of China's commercial banks from year 2004 to year 2015.

To begin with, we input data into Econometric Views and test for the stationeriness of the sequence since the analysis of an uneven sequence has no practical significance. In this paper we use the methods of Augmented Dickey-Fuller (ADF) test and Phillips-Perron (PP) test to ensure the stationeriness of the sequence, and we select the significance level of $5 \%$. The results using the ADF test and the PP test are shown respectively in 
Figure 1 and Figure 2.

We can find out that the t-statistic value of -16.727 is less than the test critical value of -1.943 under the significance level of $5 \%$ in the ADF test. In the PP test, the adjusted t-statistic value of -15.910 is also less than the critical value of -1.943 under the $5 \%$ significance level, which confirmed the results we get in the previous ADF test. Hence the logarithmic sequence of liquidity gap do not have unit root, and we can draw the conclusion that the sequence is a stationary sequence.

Then we go on with test for the inter-dependency of the logarithmic sequence of liquidity gap, which is shown in the following Figure 3. We can see from the figure that under the significance level of $5 \%$, the dependency

\begin{tabular}{|c|c|c|c|c|}
\hline & & & t-Statistic & Prob.* \\
\hline \multicolumn{3}{|c|}{ Augmented Dickey-Fullerteststatistic } & -16.72677 & 0.0000 \\
\hline \multirow[t]{3}{*}{ Test critical values: } & $1 \%$ level & & -2.581120 & \\
\hline & $5 \%$ level & & -1.943058 & \\
\hline & $10 \%$ level & & -1.615241 & \\
\hline Variable & Coefficient & Std.Error & t-Statistic & Prob. \\
\hline $\mathbf{R}(-1)$ & -1.298009 & 0.077601 & -16.72677 & 0.0000 \\
\hline R-squared & 0.661720 & \multicolumn{2}{|c|}{ Mean dependent var } & 0.000835 \\
\hline Adjusted R-squared & 0.661720 & \multicolumn{2}{|c|}{ S.D dependent var } & 0.071847 \\
\hline S.E. of regression & 0.041788 & \multicolumn{2}{|c|}{ Akaike info criterion } & -3.505507 \\
\hline Sum squared resid & 0.249709 & \multicolumn{2}{|c|}{ Schwarz criterion } & -3.484883 \\
\hline Log likelihood & 253.3965 & \multicolumn{2}{|c|}{ Hannan-Quinn criter. } & -3.497127 \\
\hline Durbin-Watson stat & 1.711399 & & & \\
\hline
\end{tabular}

Figure 1. Results of ADF test.

\begin{tabular}{lccc} 
& & Adj.t-Stat & Prob.* $^{*}$ \\
\hline \hline Philips-Perron test statistic & -15.90950 & \multirow{2}{*}{0.0000} \\
\hline Test critical values & $1 \%$ level & -2.581120 & \\
& $5 \%$ level & -1.943058 & \\
& $10 \%$ level & -1.615241 & \\
\hline \hline
\end{tabular}

*MacKinnon(1996) one-sided p-values.

\begin{tabular}{ll}
\hline \hline Residual variance(no correction) & 0.001734 \\
HAC corrected variance (Bartlett kernel) & 0.002651 \\
\hline \hline
\end{tabular}

\begin{tabular}{lcllr}
\hline \hline \multicolumn{1}{c}{ Variable } & Coefficient & Std.Error & t-Statistic & \multirow{2}{*}{ Prob. } \\
\hline \hline \multicolumn{1}{c}{ R(-1) } & -1.298009 & 0.077601 & -16.72677 & \multirow{2}{*}{0.0000} \\
\hline \hline R-squared & $\mathbf{0 . 6 6 1 7 2 0}$ & Mean dependent var & $\mathbf{0 . 0 0 0 8 3 5}$ \\
Adjusted R-squared & $\mathbf{0 . 6 6 1 7 2 0}$ & S.D dependent var & $\mathbf{0 . 0 7 1 8 4 7}$ \\
S.E. of regression & $\mathbf{0 . 0 4 1 7 8 8}$ & Akaike info criterion & $-\mathbf{3 . 5 0 5 5 0 7}$ \\
Sum squared resid & $\mathbf{0 . 2 4 9 7 0 9}$ & Schwarz criterion & $\mathbf{- 3 . 4 8 4 8 8 3}$ \\
Log likehood & 253.3965 & Hanan-Quinn criter & $-\mathbf{3 . 4 9 7 1 2 7}$ \\
Durbin-Watson stat & 1.711399 & & \\
\hline \hline
\end{tabular}

Figure 2. Results of PP test. 


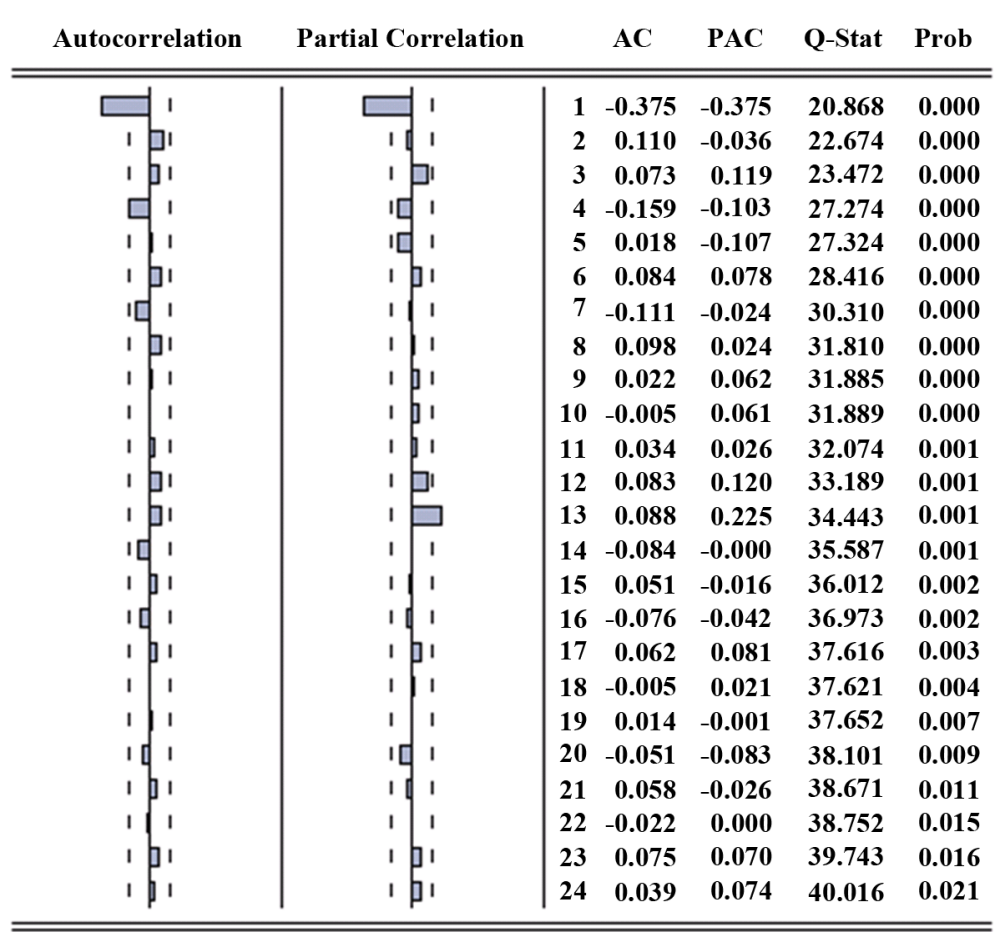

Figure 3. Correlogram of the liquidity gap logarithmic sequence.

probabilities of the Q-statistic for the logarithmic sequence of liquidity gap are much lower than 0.05 , which indicates that the sequence is not a white noise sequence, but it decays slowly and is not quite stable. So we take the first difference of the sequence. It can seen from Figure 4 that the auto-correlation of the logarithmic sequence of liquidity gap after the first difference appears to be stronger.

To figure out the best model, we take a look at the Akaike info criterion (AIC) and Schwarz criterion (SC). The selection of the value of $p$ and $q$ is based on the criterion that they would make the value of AIC and SC the smallest. And after overall consideration we choose the value of $p$ and $q$ in the model ARMA (p, q) as 2 and 3 respectively. We then get the results of ARMA model in Figure 5 through the Eviews.

The ARMA model we get is as follows:

$$
\hat{R}_{t}=-1.358 R_{t-1}-0.467 R_{t-2}+\varepsilon_{t}+0.541 \varepsilon_{t-1}-0.919 \varepsilon_{t-2}-0.569 \varepsilon_{t-3}
$$

Then we go on with the diagnosis analysis of the ARMA model to see if the model holds. We use the statistic remained in Econometrics Views and do the test for the autocorrelation of residuals. If the probability for Q-statistic exceeds the significance level of 5\%, we can say that the model does not fit so well; and if the probability for Q-statistic is below the significance level, then the model can possibly be relied on. The results of the test can be seen from Figure 6. The probabilities for Q-statistic are all less than 0.05, which indicates that the model achieves data fitting, then we can go further with the forecast based on the model we get.

\subsection{Application of Model Forecast}

We first do the forecast with dynamic method, which is shown in Figure 7. The solid line in the figure represents the predicted value for $\mathrm{R}$ and the dotted lines provide the confidence interval of twice the standard deviation. It can be seen that over time the forecasted value tends to approximate the mean of the sequence, which is close to zero. On the right of the graph is some criteria for the forecast of the model, such as the root mean squared error, the Theil inequality coefficient and its resolutions. We can see from the figure that the Theil inequality coefficient is large, which indicates that the predictive ability of the model is insufficient. However, the resolutions show that the bias proportion takes only a quite small part and the variance proportion takes a relatively large part, which indicates that the actual sequence is more volatile than the simulated sequence, which may be caused by the too long period of the forecast. 


\begin{tabular}{|c|c|c|c|c|c|c|c|}
\hline Autocorrelation & Partial Co & orrelation & & $\mathbf{A C}$ & PAC & Q-Stat & Prob \\
\hline 1 & 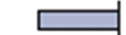 & 1 & 1 & -0.636 & -0.636 & 59.561 & 0.000 \\
\hline $1 曰$ & $\square$ & 1 & 2 & 0.170 & -0.396 & 63.817 & 0.000 \\
\hline 1 & 回 & 1 & 3 & 0.037 & -0.128 & 64.022 & 0.000 \\
\hline 1 1 & 吅 & 1 & 4 & -0.094 & -0.110 & 65.352 & 0.000 \\
\hline 111 & 뭉 & 1 & 5 & -0.019 & -0.244 & 65.409 & 0.000 \\
\hline $1 曰$ & 1 & 1 & 6 & 0.159 & -0.006 & 69.247 & 0.000 \\
\hline ․ 1 & 1 & 1 & 7 & -0.178 & -0.038 & 74.093 & 0.000 \\
\hline ים ו & 1 & 1 & 8 & 0.107 & -0.033 & 75.867 & 0.000 \\
\hline 1 & 18 & 1 & 9 & $-\mathbf{0 . 0 3 2}$ & -0.039 & 76.025 & 0.000 \\
\hline 1 & 18 & 1 & 10 & -0.019 & -0.029 & 76.079 & 0.000 \\
\hline 1 & 叫 & 1 & 11 & -0.018 & -0.109 & 76.133 & 0.000 \\
\hline 1 & 吅 & 1 & 12 & 0.038 & -0.126 & 76.358 & 0.000 \\
\hline 1 & it & ים & 13 & 0.056 & 0.108 & 76.859 & 0.000 \\
\hline 1 1 & 1 & י & 14 & -0.088 & 0.068 & 78.121 & 0.000 \\
\hline וך 1 & it & ים & 15 & 0.086 & 0.096 & 79.334 & 0.000 \\
\hline 吅 1 & 1 & 1 & 16 & -0.102 & -0.022 & 81.053 & 0.000 \\
\hline 10 & 1 & 1 & 17 & 0.072 & 0.030 & 81.908 & 0.000 \\
\hline 101 & 1 & 1 & 18 & -0.028 & 0.018 & 82.035 & 0.000 \\
\hline 1 & 1 & 1 & 19 & 0.029 & 0.038 & 82.179 & 0.000 \\
\hline 101 & 1 & 1 & 20 & -0.069 & -0.046 & 82.977 & 0.000 \\
\hline וך 1 & 1 & 1 & 21 & 0.073 & -0.047 & 83.887 & 0.000 \\
\hline I 1 & 10 & 1 & 22 & -0.074 & -0.060 & 84.825 & 0.000 \\
\hline 1 1 & 1 & 1 & 23 & 0.060 & -0.024 & 85.443 & 0.000 \\
\hline $1 \mid 1$ & 1 & 1 & 24 & -0.014 & 0.034 & 85.476 & 0.000 \\
\hline
\end{tabular}

Figure 4. Correlogram of the 1st difference liquidity gap logarithmic sequence.

\begin{tabular}{|c|c|c|c|c|}
\hline Variable & Coefficient & Std.Error & t-Statistic & Prob. \\
\hline $\mathbf{C}$ & -0.000162 & 0.000104 & -1.562737 & 0.1204 \\
\hline $\operatorname{AR}(1)$ & -1.357672 & 0.82931 & -16.37118 & 0.0000 \\
\hline $\operatorname{AR}(2)$ & -0.467183 & 0.076312 & -6.122011 & 0.0000 \\
\hline $\mathbf{A A}(\mathbf{1})$ & 0.540828 & 0.104106 & 5.194968 & 0.0000 \\
\hline $\mathbf{A A}(2)$ & -0.919309 & 0.035811 & -25.67112 & 0.0000 \\
\hline $\mathbf{A A}(\mathbf{3})$ & -0.568631 & 0.104226 & $-\mathbf{5 . 4 5 5 7 4 8}$ & 0.0000 \\
\hline R-squared & 0.809590 & \multirow{7}{*}{\multicolumn{2}{|c|}{$\begin{array}{l}\text { Mean dependent var } \\
\text { S.D. dependent var } \\
\text { Akaike info criterion } \\
\text { Schwarz criterion } \\
\text { Hanan-Quinn criter. } \\
\text { Durbin-Watson stat }\end{array}$}} & -0.000366 \\
\hline Adjusted R-squared & 0.802589 & & & 0.066479 \\
\hline S.E. of regression & 0.029537 & & & -4.164993 \\
\hline Sum squared resid & 0.118653 & & & -4.040099 \\
\hline Log likehood & 301.7145 & & & -4.114242 \\
\hline F-statistic & 115.6494 & & & 2.237242 \\
\hline Prob(F-statistic) & 0.000000 & & & \\
\hline
\end{tabular}

Figure 5. Results of the ARMA model.

The results of static forecast from January 2015 to January 2016 is presented in Figure 8. We can see from the graph that the value derived by the method of static forecast appears to be volatile, and the decline of the variance proportion indicates a better simulation of the actual sequence. The results of the forecast are proved to be ideal considering that the Theil inequality coefficient has the value of 0.60 and the covariance takes the proportion of $62 \%$, which shows that the forecast is relatively ideal. Therefore, the managers of commercial banks could achieve better liquidity risk management by means of establishing such kind of models based on historical data, setting up the stop point for liquidity loss and forecasting the liquidity risk status during a future period of time.

\section{Conclusion}

The outbreak of the unprecedented financial crisis evolved from the U.S. subprime crisis has passed for several 


\begin{tabular}{|c|c|c|c|c|c|c|c|}
\hline Autocorrelation & Partial Ce & orrelation & & $\mathbf{A C}$ & PAC & Q-Stat & Prob \\
\hline 叫 1 & 叫 & 1 & $\mathbf{1}$ & -0.133 & -0.133 & 2.5766 & \\
\hline 10 & 1 & 1 & 2 & -0.027 & -0.046 & 2.6850 & \\
\hline 1 & 1 & 1 & 3 & 0.032 & 0.022 & 2.8323 & \\
\hline 回 1 & 吅 & 1 & 4 & -0.137 & -0.134 & 5.6281 & \\
\hline$\square$. & $\square$ & 1 & 5 & -0.227 & -0.272 & 13.321 & \\
\hline ין ו & 1 & 1 & 6 & 0.096 & 0.011 & 14.710 & 0.000 \\
\hline 10 & 14 & 1 & 7 & -0.094 & -0.101 & 16.043 & 0.000 \\
\hline 101 & 1 & 1 & 8 & 0.052 & 0.010 & 16.460 & 0.001 \\
\hline ין 1 & 1 & 1 & 9 & 0.105 & 0.037 & 18.168 & 0.001 \\
\hline $10[1$ & I & 1 & 10 & -0.057 & -0.086 & 18.668 & 0.002 \\
\hline 11 & 1 & 1 & 11 & -0.022 & -0.043 & 18.740 & 0.005 \\
\hline $1 曰$ & 1 & כ כ & 12 & 0.166 & $\mathbf{0 . 1 3 2}$ & 23.097 & 0.002 \\
\hline $1 \sqrt{1}$ & 1 & 1 & 13 & -0.026 & 0.074 & 23.207 & 0.003 \\
\hline 도 1 & 당 & 1 & 14 & -0.155 & -0.153 & 27.059 & 0.001 \\
\hline וב1 & 1 & 1 & 15 & 0.066 & -0.017 & 27.755 & 0.002 \\
\hline 叫 & 10 & 1 & 16 & -0.111 & -0.075 & 29.749 & 0.002 \\
\hline 171 & 1 & 1 & 17 & 0.017 & 0.063 & 29.797 & 0.003 \\
\hline 11 & 1 & 1 & 18 & 0.020 & -0.027 & 29.862 & 0.005 \\
\hline 11 & 10 & 1 & 19 & -0.020 & -0.070 & 29.931 & 0.008 \\
\hline 吗 1 & 무 & 1 & 20 & -0.112 & -0.175 & 32.031 & 0.006 \\
\hline ים 1 & 1 & 1 & 21 & 0.113 & -0.006 & 34.199 & 0.005 \\
\hline $1 \sqrt{1}$ & 1 & 1 & 22 & -0.041 & 0.036 & 34.487 & 0.007 \\
\hline 1$] 1$ & 1 & 1 & 23 & 0.009 & -0.001 & 34.500 & 0.011 \\
\hline ים ו & 1 & 1 & 24 & 0.111 & 0.024 & 36.621 & 0.009 \\
\hline
\end{tabular}

Figure 6. Correlogram of residuals.

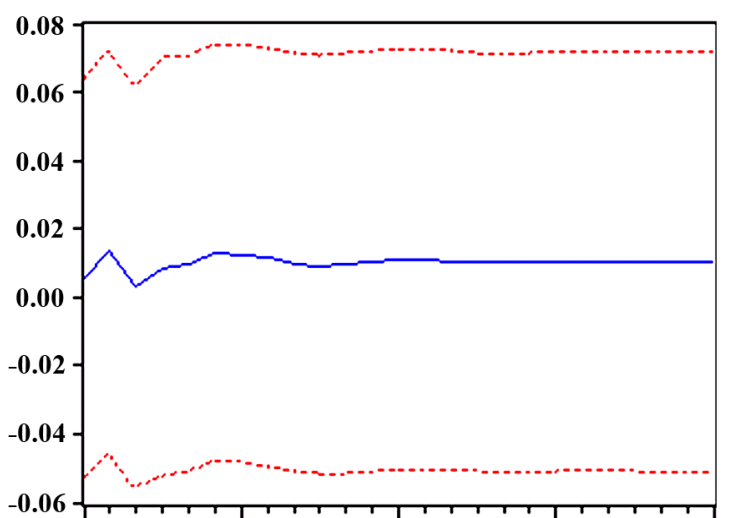

Forecast: RF

Acual: $\mathbf{R}$

Forecast sample: 2014M01 2016M01

Induded observations: 25

Root Mean Squared Error $\quad \mathbf{0 . 0 3 7 2 5 4}$

Mean Absolute Error $\quad \mathbf{0 . 0 2 7 2 7 6}$

Mean Abs.Percent Error $\quad \mathbf{3 5 5 . 5 5 4 7}$

Theil Inequality Coeffient $\mathbf{0 . 7 9 9 0 1 6}$

Bias Proportion $\quad \mathbf{0 . 0 4 9 5 2 6}$

Variance Proportion $\quad \mathbf{0 . 8 5 1 3 7 0}$

Covariance Proportion $\quad 0.099104$

Figure 7. Results of dynamic forecast.

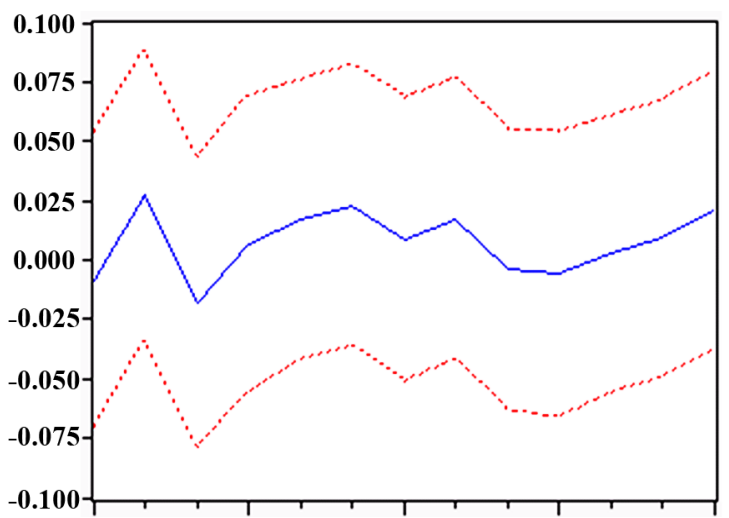

\section{RF ---- \pm 2 S.E.}

Forecast: RF

Acual: R

Forecast sample: 2015M01 2016M01

Induded observations: 13

Root Mean Squared Error $\quad \mathbf{0 . 0 2 7 9 0 5}$

$\begin{array}{ll}\text { Mean Absolute Error } & \mathbf{0 . 0 2 3 9 7 4}\end{array}$

Mean Abs.Percent Error $\quad \mathbf{6 9 7 . 1 8 6 9}$

Theil Inequality Coeffient $\mathbf{0 . 6 0 0 3 4 7}$

Bias Proportion $\quad 0.001972$

Variance Proportion $\quad \mathbf{0 . 3 7 8 1 2 0}$

\begin{tabular}{ll} 
Covariance Proportion $\quad \mathbf{0 . 6 1 9 9 0 7}$ \\
\hline
\end{tabular}

Figure 8. Results of static forecast. 
years, and the financial disturbance it brings has widely and rapidly reached every corner of the economy and taken effect. Liquidity risk management has thus become an important subject for commercial banks to make sure safety. Liquidity has always been taken as the basis for commercial banks to conduct all forms of activities, and liquidity risk has accompanied all along with the whole development process of banks and directly connected with the survival of banks as well as the stability of the financial system. The liquidity risk management of commercial banks in China is still in its infancy, we have to take measures based on our own characteristics in addition to successful experience from foreign banks. This paper detailedly narrates the status quo for the liquidity risk management of commercial banks in our country below the setting of global financial crisis through data analysis and qualitative research method after some brief introductions. Then it identifies the existing problems that we need to pay attention to, establishes the ARMA model based on the monthly data of liquidity gap and does the forecast. Finally, several corresponding suggestions have been brought up for the liquidity risk management of China's commercial banks, which is expected to provide some references for the research and practice of liquidity risk management for commercial banks.

\section{References}

[1] Saunders, A. and Cornett, M.M. (2011) Financial Institution Management-A Risk Management Approach. 7th Edition, McGraw Hill Irwin, New York.

[2] Persaud, A. (2003) Liquidity Black Holes: Understanding, Quantifying and Managing Financial Liquidity Risk. Risk Books, London.

[3] Kashyap, A., Rajan, R. and Stein, J. (2002) Banks as Liquidity Providers: An Explanation for the Co-Existence of Lending and Deposit-Taking. Journal of Finance, 57, 33-73. http://dx.doi.org/10.1111/1540-6261.00415

[4] Thomas, H. and Wang, Z.Q. (2004) Bank Securitisation and Risk Management. Mimeo.

[5] Carletti, E., Hartmann, P. and Spagnolo, G. (2007) Bank Mergers, Competition, and Liquidity. Journal of Money, Credit and Banking, 39, 1067-1105. http://dx.doi.org/10.1111/j.1538-4616.2007.00058.x

[6] Santomero, A.M. (1997) Commercial Bank Risk Management: An Analysis of the Process. Journal of Financial Services Research, 12, 83-115. http://dx.doi.org/10.1023/A:1007971801810

[7] Belkhir, M. (2012) Do Subordinated Debt Holders Discipline Bank Risk-Taking? Evidence from Risk Management Decisions. Journal of Financial Stability, 9, 705-719. http://dx.doi.org/10.1016/j.jfs.2012.01.001

[8] Sensarma, R. and Jayadev, M. (2009) Are Bank Stocks Sensitive to Risk Management? The Journal of Risk Finance, 10, 7-22. http://dx.doi.org/10.1108/15265940910924463 